\title{
TEORI MEDAN MAKNA DAN KONTEKSTUALITAS HUKUM ISLAM KONTEMPORER: REINTERPRETASI HADIS-HADIS ETIKA EKONOMI ISLAM DALAM WACANA SEMANTIK
}

\author{
Nafi'ah', Wahyu Hanafi ${ }^{2}$ \\ Institut Agama Islam Sunan Giri (INSURI) Ponorogo \\ Email; Nafiah490@gmail.com, wahyuhanafiputra@gmail.com
}

\begin{abstract}
This study aims to describe the actualization of semantic field theory in the reinterpretation of the hadiths of Islamic economic ethics. This research uses descriptive interpretive method. Actualization of semantic field theory can be explained when want to know the meaning of a word then must know the meaning of the word associated with the previous word. If viewed from the nature of the semantic relationship, then the words are grouped into a semantic field divided into 1). sintagmatic 2). set field (paradigmatic). The results of this study explain 1). Hadiths about Islamic economic ethics narrated by Ahmad and Abu Dawud with the word focus "syafä'at". contains the meaning of "mediator of goodness". The meaning of this "intermediary of goodness" is obtained through the formulation of the syntagmatic field, namely to comprehend a series of semantically interconnected words such as "double and rescue" meaning. Semantically terminology, the meaning of the word hadith is "Whosoever intercedes for a good to his brother, then he is rewarded and received, then he has come to a great door of the doors of usury. 2). Hadith about Islamic economic ethics narrated by Muslims. The word focus of the hadith is the word "gharar" which is semantically interpreted by "deception". The meaning of "deception" is obtained through the formulation of the syntagmatic field, namely by understanding the meaning of words that are still relevant to the word "deception", such as the word "unclear, and syubhat". In semantic terms, the meaning of the hadith is "Rasulullah Saw forbade buying by throwing stones and buying fraud. 3). Hadiths about Islamic economic ethics that Bukhori maintains. The focus word of the hadith is "Najsyi" which is semantically interpreted as "deceiving". The meaning of "deceiving" is derived from the paradigmatic field formulation, ie by understanding the relationship between elements at a certain level and other language elements such as "unclean, dirty, and disease" meaning. In semantic terms, the meaning of the hadith is "That the Messenger of Allah forbade buying by way of deceiving".
\end{abstract}

Keywords; Semantics, Hadith, Islamic Economic

\section{PENDAHULUAN}

Secara hierarki, hadis merupakan salah satu sumber hukum Islam yang kedua setelah al-Qur'an. Hadis menduduki posisi yang penting dalam reproduksi hukum Islam kontemporer. Saat ini, studi hadis kontemporer banyak diminati oleh beberapa kalangan pemerhati hadis modern seperti Fuat Sezgin, Nabia Abbott, dan M.M, Golziher, Joseph Schacht, yang didukung oleh G.H.A. Juynboll, meskipun beberapa dari mereka memiliki sudut pandang yang berbeda dalam 
memahami hadis. Salah satu aspek yang penting dalam studi hadis adalah studi matan hadis. Hadis sebagai sumber hukum Islam yang kedua tidak menutup kemungkinan untuk dikaji dengan berbagai metode baik yang bersifat tradisionalis maupun revisionis. Pendekatan tradisionalis dengan asumsi dan metodenya telah membuktikan kesahihan hadis disertai dengan argumen yang cukup meyakinkan. Sama halnya perspektif revisionis dengan postulat dan caranya sendiri yakni memahami hadis sebagai produk belakangan. ${ }^{1}$ Dari wacana tersebut dapat dimengerti bahwa kalangan tradisionalis telah mampu memahami hadis dengan metodologi klasik, sedangkan kalangan revisionis memandang bahwa dalam memahami sebuah hadis tidak menutup kemungkinan untuk menggunakan metodologi yang sifatnya kontemporer yang salah satunya adalah dengan pendekatan semantik ('ilm al-dalalāh) atau ilmu makna.

Bercermin dari wacana di atas, ekonomi Islam (mu'āmalah) merupakan salah satu kajian hukum Islam. Dalam studi ekonomi Islam yang paling dasar tentunya tidak terlepas dari etika ekonomi Islam. Studi etika ekonomi Islam akan mengacu pada sumber literatur hukum Islam yang salah satunya adalah hadis. Ada dua hal yang harus diperhatikan dalam studi matan hadis, pertama studi kesahihah (otentisitas) matan hadis, kedua adalah studi petunjuk (dalālah) hadis. Dari masing-masing aspek tersebut, maka hadis perlu dikaji agar mampu dipahami dan diamalkan. Kemudian, hasil studi petunjuk (dalālah) hadis maka akan ditemukan beberapa redaksi hadis yang memiliki makna pasti (qat'iy aldalālah) dan makna nisbi (zanniy al-dalālah). Kedua makna demikian dapat dikaji dengan ilmu dalalāh atau yang bisa disebut dengan ilmu semantik. Dengan demikian, memahami sebuah hadis semestinya tidak dikultuskan dengan satu pendekatan dan metode, akan tetapi alangkah baiknya hadis dipahami dengan beberapa pendekatan dan metode yang relevan dengan konteks hadis.

1 Ali Masrur, Diskursus Metodologi Studi Hadis Kontemporer: Analisa Komparatif antara Pendekatan Tradisionalis dan Pendekatan Revisionis, Journal of Qur'an and Hadith Studies, Vol. 1, No. 2 (2012), 248. 


\section{Teori Medan Makna dalam Konstelasi Linguistik}

Teori medan makna (semantic field atau lexical field) merupakan seperangkat atau kumpulan kata yang maknanya saling berkaitan. Dalam teori ini ditegaskan, bahwa agar memahami makna suatu kata, maka harus memahami pula sekumpulan kosakata yang maknanya berhubungan. ${ }^{2}$ Medan makna akan itu tersusun sebagai satu mosaik. Setiap medan makna itu akan selalu tercocokkan antar sesama medan sehingga membentuk satu keutuhan bahasa yang tidak mengenal tumpang tindih. ${ }^{3}$ Menurut Kridalaksana, medan makna adalah bagian dari sistem semantik bahasa yang menggambarkan bagian bidang kehidupan atau realitas dalam alam semesta tertentu yang direalisasikan oleh seperangkap unsur leksikal yang mempunyai hubungan makna. ${ }^{4}$

Menurut teori ini, untuk memahami makna kata harus memahami pula serangkaian kata yang secara semantis saling berhubungan. Karena itu, Lyons berpandangan bahwa makna, kata menurut teori ini adalah terciptanya hubungan antara kata tersebut dengan kata-kata lain yang berada dalam satu bidang semantis. Artinya, makna adalah pertautan yang ada diantara unsur-unsur bahasa itu sendiri. Setiap pertautan yang ada diantara unsur-unsur bahasa yang menimbulkan makna tertentu. Maka sebagai penghubung bahasa dengan dunia luar sesuai dengan kesepakatan pemakaiannya sehingga dapat saling mengerti. Adapun tujuan analisis pada bidang-bidang semantik adalah mengumpulkan setiap kata yang berada dalam bidang tertentu, lalu mengurai hubungannya dengan kata-kata yang lain. ${ }^{5}$ Dengan demikian, hal ini ditegaskan oleh Pateda bahwa medan makna merupakan seperangkat makna yang mempunyai komponen umum yang sama atau saling terjalin. ${ }^{6}$

${ }^{2}$ Mohammad Kholison, Semantik Bahasa Arab, (Sidoarjo: Lisan Arabi, 2016), 138. Menurut Pateda, makna dapat dibicarakan dengan dua pendekatan, yaitu pendekatan analitik atau referensial dan pendekatan operasional. Pendekatan analitik ingin mencari makna dengan cara menguraikannya atas segmen-segmen utama, sedangkan pendekatan operasional ingin mempelajari kata dalam penggunaanya. Pendekatan kata lebih menekankan bagaimana kata dioperasikan di dalam tindakan sehari hari. Lihat dalam Mansoer Pateda, Semantik Leksikal, (Jakarta: Rineke Cipta, 2010), 86.

3 J.D. Parera, Teori Semantik, (Jakarta: Erlangga, 2004), 139.

${ }^{4}$ Kridalaksana, Kamus Linguistik, Edisi ke-Tiga, (Jakarta: Gramedia Pustakautama, 2001), 134

${ }^{5}$ Kholison, Semantik Bahasa Arab, 139.

${ }^{6}$ Mansoer Pateda, Semantik Leksikal, 257. 
Jika dilihat dari hubungan semantis, maka kata-kata yang dikelompokkan ke dalam satu medan makna dibagi menjadi (a) kelompok medan kolokasi (sintagmatik), (b) kelompok medan set (paradigmatik). Kolokasi berarti asosiasi hubungan makna kata yang satu dengan yang lain dimana masing-masing kata tersebut memiliki hubungan ciri yang relatif tetap dan berdampingan. ${ }^{7}$ Hubungan sintagmatik bisa diibaratkan dengan hubungan satu tanda dengan tanda yang lain (misalnya antara satu kata dengan kata yang lain) dalam kesatuan yang linier. ${ }^{8}$ Sebagai contoh adalah frasa "cantik" yang masih ada relasi makna dengan "gadis", Frasa "melihat" yang tidak lepas dari peran "mata", frasa "lapar" yang identik dengan "perut", dan sebagainya.

Kemudian, medan set menunjukkan hubungan paradigmatik tentang hubungan antara unsur- unsur bahasa dalam tataran tertentu dengan unsur-unsur lain di luar tataran itu yang dapat dipertukarkan. Dan kata-kata yang berada dalam satu kelompok set itu saling bisa didistribusikan. ${ }^{9}$ Hubungan paradigmatik adalah relasi tanda-tanda dalam suatu paradigma (kesamaan umum) unit-unit memiliki kesamaan karakteristik yang menentukan keanggotaanya dalam paradigma tersebut. ${ }^{10}$ Contoh konkrit dalam hubungan paradigmatik adalah menjelang malam saya merasa lapar sekali, untung ada (---). Garis dalam kurung tersebut dapat diisi martabak, nasi goreng, roti, dan sebagainya. Kata tersebut dapat diisikan karena mempunyai referen yang sama, yakni dapat dimakan. ${ }^{11}$

Studi hubungan medan makna dalam diskursus semantik secara garis besar diklasifikasikan menjadi dua bagian, yakni medan kolokasi (sintagmatik) atau dapat disebut hubungan horizontal dan medan set (paradigmatik) atau hubungan vertikal. Kedua medan ini akan membuahkan konstruksi makna yang hampir sama dikarenakan mempunyai referen yang sama. Konstelasi makna yang dihasilkan dari dua medan ini tidak menutup kemungkinan untuk berkembang lagi. Jika mengacu pada perbendaharaan kata dan objek kontek yang akan dikaji,

${ }^{7}$ Abdul Chaer, Linguistik Umum, (Jakarta: Rineka Cipta, 2014), 317-318

${ }^{8}$ Lihat dalam Heddy Shri Ahimsa Putra, Strukturalisme Levi-Strauss: Mitos dan Budaya Sastra, (Yogyakarta: Galang Press, 2001), 40

${ }^{9}$ Kholison, Semantik Bahasa Arab, 141.

${ }^{10}$ Heddy Shri, Strukturalisme Levi-Strauss, 41.

${ }^{11}$ Abdul Chaer, Linguistik Umum, 318. 
maka makna akan selalu berkembangan dengan metodologi yang digunakan dan referen yang berbeda. Hal ini tidak menafikan relasi penanda dan petanda sebagai salah satu media konstruksi makna.

\section{METODE}

Jenis penelitian ini adalah kualitatif dengan menggunakan pendekatan (libraryresearch) deskriptif-interpretatif. Data yang diambil adalah berupa hadis-hadis etika ekonomi Islam yang diriwayatkan oleh Imam Ahmad, Abu Dawud, Bukhori, dan Muslim. Sebagai penelitian library-research, teknik pengambilan data menggunakan dokumentasi, yakni menghimpun, lterarur-literatur hadis ekonomi Islam yang bersumber dari kitab-kitab hadis Șaḥih Bukhārī, Sunan Abu Dāwwud, dan Șahīh Muslim, kemudian diklasifikasi berdasarkan klaster masing-masing. Analisis data dalam penelitian ini menggunakan grounded research, yakni mula-mula peneliti menglasifikasikan hadis-hadis etika ekonomi Islam dari kitab hadis primer tersebut kemudian dianalisis dengan teori medan makna. Analisis konten yang disandarkan pada teori medan makna akan membuahkan representasi dan inferensi makna trerkait etika ekonomi Islam (muamalah).

\section{HASIL DAN PEMBAHASAN}

\section{Ekonomi Islam sebagai Media Menjalin Solidaritas Sosial}

Sistem ekonomi yang ada selama ini belum mampu menyelesaikan persoalan ekonomi manusia secara memuaskan. Sistem Ekonomi Islam merupakan solusi yang indah atas segala persoalan yang diakibatkan dari tidak sehatnya sistem ekonomi yang berkembang selama ini. Q.S. 2: 219 menyebut

"dan mereka bertanya kepadamu apa yang mereka nafkahkan; katakanlah "yang lebih dari keperluan". ${ }^{12}$

Ini bermakna bahwa segala hal yang diperoleh oleh seorang, maka seorang tersebut harus memenuhi kebutuhan primernya terlebih dahulu, sedangkan surplusnya akan dibelanjakan ke jalan Allah. Dari sini dapat ditarik konklusi bahwasanya seorang harus senantiasa mencari rizki dengan cara yang adil dan

${ }^{12}$ Q.S. 2:219 
halal. Selanjutnya, seorang harus memenuhi kebutuhannya dengan cara yang halal dan berhati-hati. Setelah itu, apapun yang dimiliki hendaklah digunakan untuk bertasaruf di jalan Allah sembari menyejahterakan kaum miskin, miskin, anak-anak yatrim, dan beberapa dari golongan mereka yang membutuhkan.

Jika hal demikian diterapkan dengan sepenuh hati dan disertai keimanan yang kuat, maka akan berdampak kepada setiap warga masyarakat di lingkungannya akan mendapatkan tasarufnya melalui cara yang halal sesuai Islam. Impilikasi dari hal tersebut adalah berkurangnya mencari rizki secara ilegal, haram, serta praktik-praktik tidak bermoral (bunga, suap, penyelundupan, pencurian, penggelapan, malpraktik bisnis).

Cara mendapatkan rizki yang haram akan menjadi sebab terjadinya konsentrasi kekayaan di sedikit tangan sehingga menimbulkan disparitas distribusi pendapatan dan kekayaan dalam kehidupan masyarakat. Proses pencarian rizki dengan cara yang halal akan memengaruhi pola pembelanjaan/tasaruf harta dengan sikap sederhana dan tidak berlebihan. alQuran dan sunah secara tegas membantah sikap berlebihan atau melampaui batas.

Bersikap bijak dalam mengelola kelebihan harta yang dimiliki dapat diwujudkan dengan bersedekah kepada yang membutuhkan, jihad pada jalan Allah Swt melalui jalur pendidikan-keagamaan, membebaskan hutang seorang, menolong anak yatim, fakir, miskin, janda, duda, dan duafa.

Kemudian, prinsip umum yang harus dipahami dalam menjalankan kegiatan muamalah adalah penerapan etika Islam. Etika muamalah (ekonomi Islam) merupakan kebutuhan dasar dalam bermuamalah. Dengan adanya etika, muamalah tidak akan merugikan satu pihak. Etika juga menjadi pondasi bangunan muamalah agar senantiasa berlangsung dan mendapatkan rida Allah Swt. Berikut adalah prinsip-prinsip muamalah dalam Islam;

\section{Al-Huryah (kebebasan)}

Prinsip ini berarti bahwa seorang individu telah diberi kebebasan oleh Allah Swt untuk mencari harta, memiliki, menikmati serta membelanjakannya sesuai dengan kehendaknya. Seorang juga diberi kebebasan dalam menentukan objek 
perjanjian dan menentukan dengan siapa ia akan membuat perjanjian. Selain itu, seorang juga diberi kebebasan dalam menentukan penyelesaian sengketa muamalah jika terjadi di kemudian hari. Prinsip demikian memiliki arti bebas untuk memilih profesi, bisnis maupun lapangan kerja guna mencari nafkah. Namun, Islam tidak memberi batasan kebebasan dalam lapangan ekonomi berdasarkan syariat Islam.

2. Al-Musāwah (persamaan dan kesetaraan)

Prinsip ini mengandung pengertian bahwa para pihak mempunyai kedudukan (bargaining position) yang sama, sehinggga dalam menentuakan term and condition dari suatu akad atau perjanjian setiap pihak mempunyai kesetaraan dan kedudukan yang seimbang.

3. Al-'Adālah (keadilan)

Prinsip Islam mengenai keadilan berlaku di seluruh aspek kegiatan manusia baik di bidang hukum, sosial, politik maupun ekonomi. Dalam melaksanakan suatu perjanjian/akad menuntut para pihak terkait untuk melakukan segala hal yang ditentukan dalam mengungkap kehendak, keadaan, dan memenuhi semua kewajiban. Perjanjian harus senantiasa mendatangkan keuntungan yang adil dan seimbang. Perjanjian tidak boleh mendatangkan kerugian bagi salah satu pihak. Sistem ekonomi Islam menjadikan prinsip keadilan sebagai dasar segala aspek perekonomian seperti produksi, distribusi, konsumsi, dan pertukaran.

4. Al-Rị̂ā (kerelaan)

Prinsip ini menyatakan bahwa segala transaksi yang dilakukan harus atas dasar kerelaan antara masing-masing pihak dan tidak boleh ada unsur paksaan, tekanan, penipuan, dan mis-statemen.

5. Al-Ṣidq (kebenaran dan kejujuran)

Islam melarang perilaku menipu dan berbohong, karena perilaku keduanya tersebut sangat berpengaruh terhadap keabsahan perjanjian/akad. 


\section{Al-Kitābah (tertulis)}

Bahwa setiap perjanjian dibuat secara tertulis, lebih berkaitan demi kepentingan pembuktian jika di kemudian hari terjadi sengketa. ${ }^{13}$

Paradigma sistem ekonomi tidak terlepas dari paradigma sosial budaya. Paradigma masyarakat Islam dalam suatu ikatan individu dan masyarakat yang satu dengan yang lain bagaikan satu tubuh. Jika satu unsur tubuh sakit, semua akan merasa menderita pula. Itulah keistimewaan doktrin masyarakat muslim. Doktrin demikian juga berlaku dalam kegiatan ekonomi/muamalah.

Seperti halnya prinsip jual beli. Sebagai cara untuk memperoleh hak milik atas harta atau barang dan jasa harus didasarkan atas kesadaran pertukaran manfaat, tolong-menolong sesama manusia, dan saling tanggung renteng atas resiko yang terjadi dalam proses transaksi. Begitu juga dalam kegiatan perdagangan barang dan jasa yang loss and profit sharing. Dalam kegiatan perbankan, konsekuensi yang didapat adalah diharamkannya interest (bunga). Di dalamnya terdapat sarat dengan unsur-unsur riba, maisir (perjudian) dan gharār (penipuan). Tiga hal ini yang menjadi biang keladi keserakahan dan ketidakadilan dalam kehidupan bermuamalah. Akibatnya adlaah, tidak meratanya hasil yang didapat bagi p[ara pelaku ekonomi. Hal ini sudah barang tentu menyalahi prinsip musāwah dalam bermuamalah.

Perihal yang lain adalah masalah riba. Riba adalah unsur yang menyeret seorang untuk menjadi tidak produktif dan bahkan cenderung mengekploitasi orang lain. Maisir adalah kelanjutan dari unsur riba, yakni unsur gambling (perjudian) dalam melaksanakan kegiatan ekonomi yang dapat merusak laju kendali dan pertumbuhan produktif, distributif, dan konsumtif. Sedangkan gharār yang tidak terlihat adalah adanya pihak-pihak terkait/pelaku ekonomi yang tertipu dalam proses transaksi semu dengan alasan bantuan pembiyaan yang dibebani fixed interest. Fixed interest secara teologis adalah mendahului takdir Tuhan. Sementara bagi hasil atau musyarakah, mudarabah dan akad-akad

13 Abdul Ghofur Anshori, Hukum Perjanjian Islam di Indonesia, (Konsep, Regulasi dan Implementasi), (Yogyakarta: Gadjah Mada University Press, 2010), 32. 
ekonomi Islam yang lain adalah kesadaran akan adanya intervensi Tuhan yang tidak terlihat atau invisible hand dalam segala tindak tanduk manusia.

Dari kesadaran sebagaimana dijelaskan di atas, jika para pelaku ekonomi memperoleh laba/ keunatungan, maka akan segera tersadar untuk mengeluarkan zakat dan infak. Sebaliknya, jika mereka mengalami kerugian, maka akan segera menyadari keterbatasan manusia sambari tetap berusaha dan tawakal terhadap Allah Swt.

Atas segala kelebihan yang dimiliki sistem ekonomi Islam di atas, maka sudah saatnya para pelaku ekonomi saling berbenah untuk menerapkan sistem ekonomi syariah sebagi instrumen kebijakan ekonomi guna menguatkan dan membangun ekonomi nasional yang tidak sebatas dalam sektor keuangan/finansial, tetapi juga harus masuk dalam sektor ekonomi yang lebih komperhensif dan luas di skala makro mupun mikro. Banyak yang berkeyakinan sistem ekonomi Islam akan mampu menciptakan kemakmuran dan kesejahteraan masyarakat yang adil di bawah lindungan Allah Swt.

Hadirnya prinsip etika ekonomi Islam dalam bermuamalah tidak lain karena masyarakat muslim khususnya harus menerapkan maqāṣid al-syarī'ah sebagaimana diperintahkan dalam syariat Islam. Maqāṣid al-syarī'ah hadir guna menjaga kelestarian masyarakat muslim khususnya. Guna melangsungkan misi tersebut, perlunya kesadaran pada tiap individu untuk memperbaiki diri dalam segala tindak tutur dan perilaku yang berkenaan dengan muamalah. Muamalah merupakan jembatan interaksi indivdu dan sosial. Sebagai media transisi, sudah selayaknya jika muamalah memiliki aturan-aturan normatif yang berasas pada syariat Islam. Misi ini tidak lain adalah untuk kebaikan bersama dan mengharap rida Allah Swt.

\section{Reinterpretasi Hadis-hadis Etika Ekonomi Islam dalam Wacana Semantik}

Etika merupakan salah satu unsur yang penting dalam bermuamalah. Perintah untuk bermuamalah sesungguhnya dikuatkan oleh Allah Swt melalui al-Qur'an. Adanya etika dalam bermuamalah merupakan salah satu tujuan syariah (maqāsid al-syarī'ah) yaitu menjaga harta (hifz al-māl). Dengan diaturnya etika menurut 
syara' diharapkan manusia mampu bermuamalah dengan baik tanpa merugikan orang lain. Aturan etika dalam bermuamalah khususnya dalam bidang ekonomi juga telah disampaikan Rasulullah Saw dalam beberapa hadis. Hadis-hadis tersebut diriwayakan oleh beberapa Rawi sebagai bentuk kontekstualisasi apa yang dilakukan oleh Rasulullah Saw. Berikut hadis-hadis etika ekonomi Islam yang dikaji melalui pendekatan semantik.

Hadis pertama, hadis tentang etika ekonomi Islam yang diriwayatkan oleh Ahmad dan Abu Dawud dengan kata fokus "syafä'at": 14

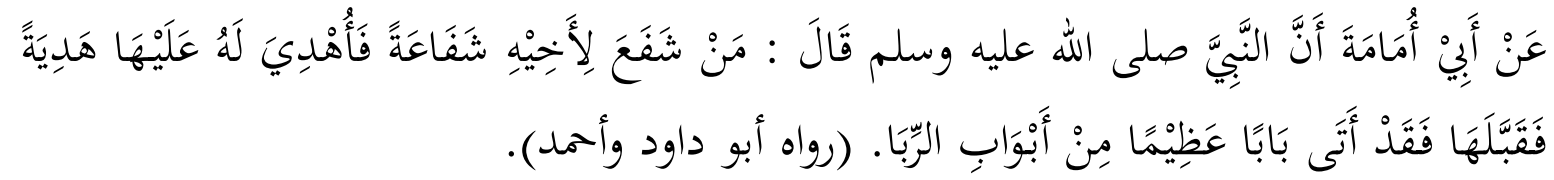

Artinya; Dari Abi Umamah, bahwasanya nabi Saw bersabda Barang siapa memberi syafa'at (pertolongan) kepada saudaranya kemudian ia diberi hadiah akan hal itu dan menerimanya, maka ia telah memasuki pintu-pntu riba. (H.R. Abu Dawud dan Ahmad).

Makna kata "syafä'at" dalam hadis tersebut adalah "perantara kebaikan". Makna "syafä'at"menurut Ibnu Ashim adalah perantara kepada orang lain dengan memberi manfaat atau menolak kemadharatan. Makna "perantara kebaikan" ini didapat dengan formulasi medan sintagmatik, yakni memahami serangkaian kata yang secara semantis saling berhubungan seperti makna "ganda dan pertolongan". Kata fokus "perantara kebaikan" dalam redaksi hadis tersebut merupakan konstruksi makna yang dimunculkan dengan referen yang sesuai dengan unsur-unsur kebahasaan secara liner. Makna "perantara kebaikan" lebih mendekati pada makna "suap". Secara terminologi semantis, arti hadis tersebut adalah "barang siapa menjadi perantara untuk suatu kebaikan kepada saudaranya lalu ia diberi hadiah dan diterimanya, maka ia telah mendatangi sebuah pintu besar dari pintupintu riba".

Maksud hadis tersebut adalah bahwasanya Rasulullah Saw melarang umatnya jika menolong sesamanya dengan menggunakan unsur "suap" atau "risywah". Dalam redaksi hadis yang lain juga dijelaskan bahwa orang yang menyuap dan orang yang disuap maka akan masuk neraka. Risywah jelas tidak dibenarkan secara syara'. Secara fikih muamalah, pemberian seseorang kepada

14 Abu Dawud, Sunan Abu Dāwud, (Bairut: Maktab Dirāsāh wa al-Buḥūis, tt), 3541 
orang lain harus dilandasi dengan unsur keikhlasan. Ikhlas dalam artian tidak mengharap apapun selain rida Allah Swt termasuk hadiah yang diberikan kepada penolong. Hal ini dikuatkan dengan etika bisnis Islam yang menjelaskan bahwa dalam transaksi bisnis Islam harus ada keikhlasan dari masing-masing pihak untuk saling mempertukarkan aset masing-masing baik uang dengan barang, uang dengan manfaat, dan uang dengan pengalihan tanggung jawab.

Kedua, hadis yang diriwayatkan oleh Jamaah kecuali Bukhori: ${ }^{15}$

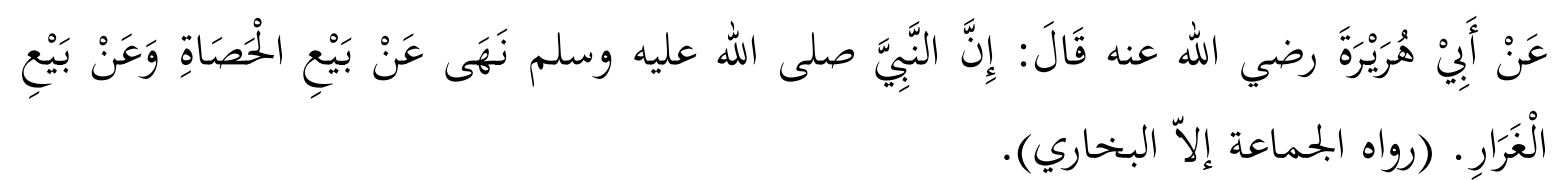

Artinya; Dari Abu Hurairah RA, ia mengatakan bahwasanya nabi Muhammad Saw melarang jual-beli dengan cara melempar batu dan jual-beli penipuan (H.R. Jamaah dan Bukhari).

Kata fokus dalam kajian semantik dalam hadis tersebut adalah "gharar" yang secara etimologi mempunyai arti membahayakan atau penjualan sesuatu yang tidak terang rupa dan sifatnya. ${ }^{16}$ Makna leksikologi ini membawa pengertian bahwa pengertian terhadap sesuatu yang tidak jelas baik bentuk dan sifatnya. Sesuatu yang dijual mempunyai nilai nihilisme tanpa perwujudan yang konkrit akan menggiring pembeli pada tahap dusta. Ditinjau dari sisi medan makna, maka akan lebih tepat dimaknai dengan kata "penipuan". Makna "penipuan" didapat dengan formulasi medan sintagmatik, yakni dengan memahami makna kata yang masih relevan dengan kata "penipuan", seperti kata "belum jelas, tidak jelas, dan syubhat". Konstruksi makna demikian dimulai dari penyesuaian referen yang relevan dengan makna yang dituju. Jika mengacu pada pendekatan semantis, arti hadis tersebut adalah "Rasulullah Saw melarang jual-beli dengan cara melempar batu dan jual-beli penipuan.

Rasulullah Saw dengan tegas melarang umatnya untuk menipu sesamanya melalui akad jual-beli. Hal demikian dapat dimanifestasikan dalam bentuk transaksi jual-beli. Dalam al-Qur'an dijelaskan bahwa Islam menghalalkan jualbeli dan mengharamkan riba. Akad jual-beli yang dimaksud di sini adalah jual-

${ }^{15}$ Imam Muslim, Șậhh Muslim, (Bairut: Maktab Dirāsāh wa al-Buhūis, tt), 1153

16 A.W Munawwir, Kamus al-Munawwir: Arab-Indonesia, Edisi ke-Dua, (Surabaya: Pustaka Progresiff, 1997), 1001. 
beli yang telah memenuhi syarat dan rukunnya. Jual-beli yang telah memenuhi syarat dan rukunnya akan memiliki nilai keabsahan secara syara'. Islam tidak mempebolehkan transaksi jual-beli suatu barang yang bersifat masih samar, syubhat, dan menipu, seperti halnya menjual hasil buah-buahan yang diasumsikan matang ke depannya akan tetapi saat ini masih dalam bentuk biji-bijian yang baru ditanam. Jika transaksi ini dilakukan, maka hukum akad jual-beli bisa dianggap batal karena adanya unsur penipuan. Dilarangnya jual-beli dengan sistem "gharar" dengan maksud agar antara penjual dan pembeli saling mendapatkan keuntungan, tidak ada yang dirugikan di salah satu pihak. Inti transaksi bisnis maupun jual-beli dalam Islam tidak sebatas label melainkan harus memperhatikan penerapan prinsip dan etika Islam di dalamnya. Dalam beberapa sumber disebutkan bahwa etika bisnis Islam diantaranya adanya prinsip kejujuran, saling rela, persamaan, tidak menipu, ke-tauḥid-an, dan lain sebagainya. Dari sini sudah jelas bahwasanya jenis penipuan dalam bentuk apapun tidak dibenarkan secara syara' dan etika bisnis Islam.

Ketiga, hadis etika ekonomi Islam yang diriwayatkan oleh Bukhari:17

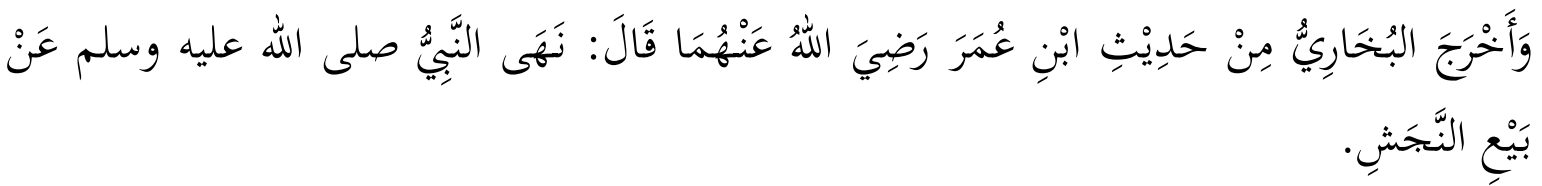

Artinya; Diriwayatkan oleh Bukhari dari hadis Ibnu Umar RA, ia mengatakan bahwasanya Rasulullah melarang jual-beli dengan cara memperdaya.

Kata fokus dalam kajian semantik dalam hadis tersebut adalah "al-Najsy" yang merupakan derivasi dari kata kerja (fi'il) "najasya-yanjasyu-najsyan" dengan makna "mengeluarkan". Dalam hal jual-beli yang artinya "menawar dengan maksud agar orang lain menawar lebih tinggi. ${ }^{18}$ Syafii memberikan pengertian bahwa "al-najsy" adalah seseorang yang menawar suatu barang yang diperjual belikan dengan maksud agar orang lain memberi tawaran harga yang lebih tinggi. ${ }^{19}$ Secara medan makna, makna "memperdaya" terkonstruksi dengan formulasi medan paradigmatik, yakni dengan memahami hubungan antara unsur-unsur pada tataran tertentu dengan unsur-unsur bahasa pada tataran lain,

${ }^{17}$ Imam Bukhari, Șahịh Bukhārī, Bairut: (Maktab Dirāsāh wa al-Buhūis, tt), 3099.

18 A.W Munawwir, Kamus al-Munawwir, 1390.

${ }^{19}$ Ibnu Hajar, Fathul Bārī, Juz-4 (Bairut: Dār al-Ihyyā' al-'Araby), 417. 
seperti contoh makna "yang najis, kotor, dan penyakit". Konstruksi makna demikian berawal dengan mengacu pada referen yang akan dijadikan objek bahasa. Kata "al-najsy" yang secara etimologi memiliki makna "mengeluarkan", akan lebih tepat jika disejajarkan dengan makna konteks dalam redaksi hadis, yakni "memperdaya". Pembuahan makna diupayakan dengan mengaitkan antara makna yang dituju dengan kesesuaian redaksi hadis. Dalam terminologi semantis, hadis tersebut dapat diartikan "bahwasanya Rasulullah melarang jual-beli dengan cara memperdaya".

Rasulullah Saw menegaskan dalam hadis tersebut kepada umatnya agar bemuamalah dengan sistem jual-beli tanpa ada unsur memperdaya sesamanya. Jual-beli dengan sistem "al-Najsy" dihukumi batal dan tidak halal. ${ }^{20}$ Seperti dijelaskan sebelumnya, bahwa akad jual-beli yang sah adalah akad jual-beli yang memenuhi syarat dan rukunnya. Selama akad jual-beli tersebut tidak memenuhi syarat dan rukun yang telah ditentukan oleh syara', maka akan menjadi batal. Seperti halnya jual-beli menggunakan sumpah, yang mana sumpah tersebut dimaksudkan untuk memperdaya dan mempengaruhi pembeli agar mau membeli dengan harga yang diinginkan oleh penjual. Jual-beli sumpah tidak dibenarkan dalam Islam karena mempunyai sifat memperdaya orang lain dalam menentukan sebuah keputusan. Dalam etika bisnis Islam terdapat unsur etika kebebasan untuk memiliki barang yang diinginkan tanpa ada pihak yang dirugikan. Dengan demikian, jika penjual berusaha memperdaya pembeli dengan berbagai bentuk unsur penipuan baik dengan sumpah ataupun yang lain maka dinilai menyalahi aturan etika bisnis Islam yang mengakibatkan batal atau rusaknya syarat sah jual beli.

${ }^{20}$ Abdullah Ibn Ahmad Ibn Qadamah, Fiqh al-Muqāran, (Bairut: Dār al-Ihyā' al-'Araby), 149. 


\section{SIMPULAN}

Dalam membuahkan makna pada teks, diperlukan pendekatan dan metode yang relevan. Salah satu pendekatan yang digunakan dalam kajian teks adalah pendekatan semantik. Diskurusus semantik sebagai salah satu pendekatan linguistik modern memiliki beberapa teori makna. Teori-teori makna demikian digunakan dalam studi linguistik mikro dan makro. Salah satu objek material yang relevan dalam kajian teori makna dalah teks hadis. Teori medan makna merupakan salah satu teori makna dalam wacana semantik yang memberikan arti bahwa ketika hendak memahami makna suatu kata, maka harus memahami makna serangkaian kata yang berkaitan dengan makna tersebut. Dalam wacana ini, makna kata akan berhubungan dengan makna lain dalam medan semantis.

Hadis merupakan salah satu sumber hukum Islam yang kedua setelah alQur'an. Hadis menduduki posisi yang sangat penting dalam reproduksi hukum Islam kontemporer. Eksistensi hadis sebagai teks tidak menutup kemungkinan mengalami pergeseran wacana. Semantik sebagai salah satu pendekatan revisionis guna memahami teks memiliki signifikasi interpretasi. Menggunakan teori medan makna dalam wacana hadis, berarti mengaktualisasikan formulasi makna kata fokus dalam hadis serta berupaya memahami makna kata yang masih berkaitan dengan kata fokus. Dengan demikian, reinterpretasi kata fokus dalam hadis dapat dimengerti sesuai dengan medan semantis.

Aktualisasi teori medan makna dalam hadis-hadis etika ekonomi Islam diantarannya adalah 1). Hadis tentang etika ekonomi Islam yang diriwayatkan oleh Ahmad dan Abu Dawud dengan kata fokus "syafä'at". Makna kata "syafä'at" dalam hadis tersebut adalah "perantara kebaikan". 2). Hadis etika ekonomi Islam yang diriwayatkan oleh Muslim. Kata fokus dari hadis tersebut adalah kata "gharar" yang secara semantis dimaknai dengan "penipuan". 3). Hadis etika ekonomi Islam yang diriwatkan oleh Bukhori. Kata fokus dari hadis tersebut adalah "Najsyi" yang secara semantis dimaknai dengan "memperdaya". Dengan demikian, makna-makna dari kata fokus dalam redaksi hadis-hadis etika ekonomi Islam tersebut dilahirkan dengan memahami makna kata yang masih berkaitan dengan kata fokus tersebut. Teori medan makna dalam wacana semantik turut 
berkontribusi dalam reproduksi hukum Islam kontemporer. Aktualisasi teori ini digunakan agar wacana reproduksi hukum Islam kontemporer menyesuaikan dengan pendekatan dan metode reproduksi hukum Islam yang sesuai dengan pergeseran zaman.

\section{BIBLIOGRAFI}

A.W Munawwir. 1997. Kamus al-Munawwir: Arab-Indonesia, Edisi ke-Dua. Surabaya: Pustaka Progresiff.

Ahimsa Putra, Heddy Shri. 2001. Strukturalisme Levi-Strauss: Mitos dan Budaya Sastra. Yogyakarta: Galang Press.

Ahmad Ibn Qadamah, Abdullah Ibn. tt. Fiqh al-Muqāran. Bairut: Dār al-Iḥyā' al-'Araby.

Anshori, Abdul Ghofur. 2010. Hukum Perjanjian Islam di Indonesia. Konsep, Regulasi dan Implementasi. Yogyakarta: Gadjah Mada University Press.

Bukhari, Imam. tt. Ṣahīh Bukhārī, Bairut. Maktab Dirāsāh wa al-Buḥūis.

Chaer, Abdul. 2014. Linguistik Umum. Jakarta: Rineka Cipta.

Dawud, Abu. tt. Sunan Abu Dāwud. Bairut: Maktab Dirāsāh wa al-Buḥūis.

Hajar, Ibnu. tt. Fatḥul Bārī, Juz-4. Bairut: Dār al-Iḥyā' al-'Araby.

J.D. Parera. 2004. Teori Semantik. Jakarta: Erlangga.

Kholison. 2016. Semantik Bahasa Arab. Sidoarjo: Lisan Arabi.

Kridalaksana. 2001. Kamus Linguistik, Edisi ke-Tiga. Jakarta: Gramedia Pustakautama

Masrur, Ali. 2016. Diskursus Metodologi Studi Hadis Kontemporer: Analisa Komparatif antara Pendekatan Tradisionalis dan Pendekatan Revisionis, Journal of Qur'an and Hadith Studies, Vol. 1, No. 2.

Muslim, Imam. tt. Ṣaḥih Muslim. Bairut: Maktab Dirāsāh wa al-Buhūis.

Pateda, Mansoer. 2010. Semantik Leksikal. Jakarta: Rineke Cipta.

S. Pradja Juhaya. 2012. Ekonomi Syariah. Bandung: Pustaka Setia.

Sharif chaudhry Muhammad. 2016. Sistem Ekonomi Islam: Prinsip Dasar. 